$$
\text { CONF. } 961202--15
$$

\title{
DIRECT CONVERSION OF HALOGEN-CONTAINING WASTES TO BOROSILICATE GLASS
}

C. W. Forsberg, E. C. Beahm, and J. C. Rudolph

Oak Ridge National Laboratory*

P.O. Box 2008

Oak Ridge, Tennessee 37831-6180

Tel: (423) 574-6783

Fax: (423) 574-9512

Email: forsbergcw@ornl.gov

December 9, 1996

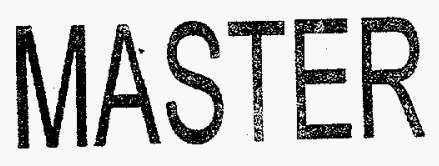

Prepared for

Material Research Society 1996 Fall Meeting: Symposium II

Scientific Basis For Nuclear Waste Management XX

Materials Research Society

Boston, Massachusetts

December 2 - 6, 1996

Symposium II; Log No. 5471

Keywords

Glass, GMODS, Halides, Waste, Borosilicate Glass

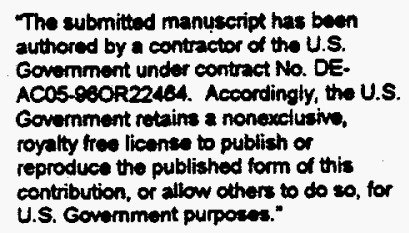

"Managed by Lockheed Martin Energy Research Corp. under contract DE-AC05-96OR22464 for the U.S. Department of Energy. 


\section{DISCLAIMER}

This report was prepared as an account of work sponsored by an agency of the United States Government. Neither the United States Government nor any agency thereof, nor any of their employees, makes any warranty, express or implied, or assumes any legal liability or responsibility for the accuracy, completeness, or usefulness of any information, apparatus, product, or process disclosed, or represents that its use would not infringe privately owned rights. Reference herein to any specific commercial product, process, or service by trade name, trademark, manufacturer, or otherwise does not necessarily constitute or imply its endorsement, recommendation, or favoring by the United States Government or any agency thereof. The views and opinions of authors expressed herein do not necessarily state or reflect those of the United States Government or any agency thereof. 


\section{DISCLAMER}

Portions of this document may be illegible in electronic image products. Images are produced from the best available original document. 


\title{
DIRECT CONVERSION OF HALOGEN-CONTAINING WASTES TO BOROSILICATE GLASS
}

\author{
C. W. FORSBERG, E. C. BEAHM, and J. C. RUDOLPH \\ Oak Ridge National Laboratory, Oak Ridge, TN 37831, forsbergcw@ornl.gov
}

\begin{abstract}
Glass has become a preferred waste form worldwide for radioactive wastes; however, there are limitations. Halogen-containing wastes can not be converted to glass because halogens (chlorides, fluorides, etc.) form poor-quality waste glasses. Furthermore, halides in glass melters often form second phases that create operating problems. A new waste vitrification process, the Glass Material Oxidation and Dissolution System (GMODS), removes these limitations by converting halogen-containing wastes into borosilicate glass and a secondary, clean, sodium-halide stream.
\end{abstract}

\section{INTRODUCTION}

Major difficulties exist in the processing and disposal of halogen-containing radioactive wastes such as halogen-containing plastics, incinerator ash from the processing of halogen-containing wastes, plutonium residues [1], Molten Salt Reactor Experiment (MSRE) wastes, and electrometallurgical spent nuclear fuel process wastes. Halides, such as fluorides, chlorides, and iodides, generally make poor-quality waste forms. The analogy used in waste management is that good waste forms (silica, titanates, etc.) for radioactive materials can be found at any ocean beach. Materials that dissolve in water (halides etc.) make poor storage forms.

Glass has become a preferred waste form worldwide for immobilizing radioactive wastes, but like other waste forms, halides in glass result in poor-quality glasses. Furthermore, traditional glass-making operations have encountered major operational difficulties with halides in the melters. With current technology, halide-containing wastes must first be processed to remove the halogens before the wastes can be converted to glass. This process is an expensive and a complex step.

A new waste vitrification process, the Glass Material Oxidation and Dissolution System (GMODS), has been invented [2,3] to convert halogen-containing wastes to borosilicate glass and a secondary sodium-halide stream. The process also (1) converts metals, ceramics, and amorphous solids to glass and (2) oxidizes organics and then converts the residue to glass.

\section{GMODS PROCESS DESCRIPTION}

GMODS converts wastes into glass within a melter or melters. The process (Fig. 1) can operate as either a sequential batch or continuous process. The starting conditions are a glass melter filled with molten, lead-borate dissolution glass containing $2+$ mol of lead oxide $(\mathrm{PbO})$ per mole of boron oxide $\left(\mathrm{B}_{2} \mathrm{O}_{3}\right)$ and initial temperatures of 800 to $1000^{\circ} \mathrm{C}$.

\section{Addition of Feed Materials To The Molten Dissolution Glass (Fig, 1, Sect. 1)}

The oxide and amorphous components in the feed dissolve into the molten glass. While metals and organics do not dissolve into conventional molten glasses, the GMODS dissolution glass has 


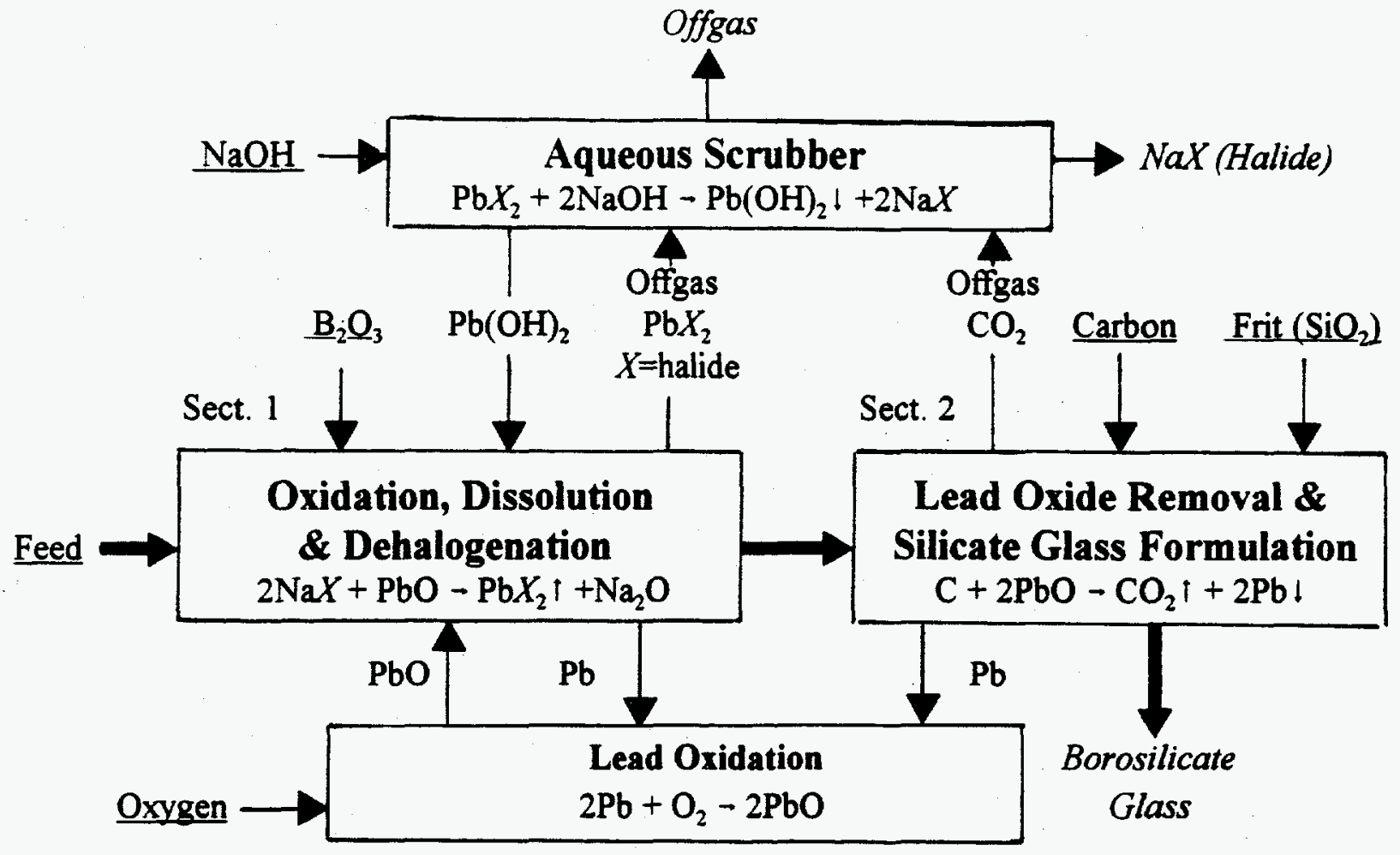

FIGURE 1. GMODS processing of halogen wastes to borosilicate glass.

special properties that permit the processing of these materials in situ. The inclusion of the sacrificial oxide - $\mathrm{PbO}$-in the molten glass provides a method to oxidize in situ (a) metals [Me] to metal oxides $\left[\mathrm{Me}_{\mathrm{y}} \mathrm{O}_{\mathrm{x}}\right]$ and (b) organics to carbon dioxide $\left(\mathrm{CO}_{2}\right)$ gas and steam. These metal oxides dissolve into the glass; carbon oxides (in gaseous form) and steam exit the melter. The $\mathrm{B}_{2} \mathrm{O}_{3}$ in the melt ensures the rapid dissolution into the glass of (a) protective oxide layers on metal wastes and (b) refractory oxide-like wastes such as those found in some incinerator ashes. The $2 \mathrm{PbO}: \mathrm{B}_{2} \mathrm{O}_{3}$ ratio in the dissolution glass is chosen to maximize chemical reaction rates and assure high solubility of oxides in the glass. The reaction product, molten lead, separates from the glass and sinks to the bottom of the melter to form a separate layer.

$$
\begin{gathered}
\mathrm{yMe}+\mathrm{zPbO}-\mathrm{Me}_{y} \mathrm{O}_{z}+\mathrm{zPb} \downarrow \\
\mathrm{C}+2 \mathrm{PbO}-\mathrm{CO}_{2} \uparrow+2 \mathrm{~Pb} \downarrow
\end{gathered}
$$

In the dissolution glass, halogens in the waste react with the $\mathrm{PbO}$ to form lead halide compounds. For example, chlorides in the waste form lead chloride $\left(\mathrm{PbCl}_{2}\right)$, which is volatile at glass melter temperatures and exits to the aqueous sodium hydroxide $(\mathrm{NaOH})$ scrubber. In the scrubber, the $\mathrm{PbCl}_{2}$ reacts with the $\mathrm{NaOH}$ to yield insoluble lead hydroxide $\left[\mathrm{Pb}(\mathrm{OH})_{2}\right]$ and soluble sodium chloride $(\mathrm{NaCl})$. The $\mathrm{Pb}(\mathrm{OH})_{2}$ is recycled back to the melter, in which it decomposes to $\mathrm{PbO}$ and steam $\left(\mathrm{H}_{2} \mathrm{O}\right)$, while the aqueous $\mathrm{NaCl}$ stream is cleaned and discharged as a chemical waste.

For halogen removal, there are two primary requirements: (1) low-viscosity glass such as to allow the rapid escape of gaseous lead dihalide compounds from the glass and (2) sufficiently 
volatile halide compounds. Measurements of glass viscosity in the dissolution glass show that this system has very low viscosities. Thermodynamic analysis and literature data indicate that the lead dihalides are volatile.

\section{Formation of Borosilicate Glass (Fig. 1, Sect. 2)}

After dissolution of the wastes, silicon oxide $\left(\mathrm{SiO}_{2}\right)$ and other additives are introduced to the glass to produce a high-quality glass. Excess $\mathrm{PbO}$ is removed from the glass by adding carbon, which converts the $\mathrm{PbO}$ to lead metal and carbon dioxide $\left(\mathrm{CO}_{2}\right)$. The lead metal sinks to the bottom of the melter as a separate phase as the $\mathrm{CO}_{2}$ exits via the off-gas system. The final glass may have some or no $\mathrm{PbO}$ depending upon the desired product glass. The product glass is poured from the melter into the canister.

\section{Recycle of Lead Metal}

Lead metal from the different chemical reactions is oxidized to $\mathrm{PbO}$ with oxygen and recycled back to the beginning of the process. Lead does not leave the system. The oxidation reaction is

$$
2 \mathrm{~Pb}+\mathrm{O}_{2} \rightarrow 2 \mathrm{PbO}
$$

\section{EQUIPMENT}

The GMODS equipment configuration depends upon the scale of operation. For throughputs from a few kilograms to several thousand metric tons per year, batch operations are possible with a single melter. In a batch operation, each step is done sequentially: (1) oxidation, dissolution and dehalogenation; (2) PbO removal and frit addition to form borosilicate glass; (3) pouring of product glass into containers while leaving the lead metal at the bottom of the melter; and (4) regeneration of the dissolution glass by oxidation of the lead metal in the melter with $\mathrm{O}_{2}$ and addition of $\mathrm{B}_{2} \mathrm{O}_{3}$.

For larger-scale operations, continuous processing equipment would be preferred. In this context, it is recognized the GMODS has similarities to several state-of-the-art lead-smelter processes such as the Queneau-Schuhmann-Lurgi (QSL) continuous lead-smelting process [4]. The QSL furnace has an oxidizing zone (similar to the oxidizing dissolution step in the GMODS process) and a reducing zone (similar to the removal of excess $\mathrm{PbO}$ and conversion to borosilicate glass step in the GMODS process).

In the QSL oxidizing zone, oxygen and $\mathrm{PbO}$ convert molten slag feed materials (lead sulfide ores and recycle lead battery materials with some organics) to (1) $\mathrm{PbO}$ that remains in the slag; (2) lead metal that separates from the slag and sinks to the bottom of the system; and (3) an offgas stream of sulfur oxides, carbon oxides, and steam. In the QSL reducing step, carbon (coal) is added to the molten glassy slag containing feed impurities and $\mathrm{PbO}$. The $\mathrm{PbO}$ is reduced to metal that separates from the slag and sinks to the bottom of the furnace. The glassy slag low in $\mathrm{PbO}$ is discharged as a waste. Much (but not all) of the chemistry in the two processes is identical. GMODS is optimized to produce a high-quality glass, whereas QSL is optimized for economic lead recovery from ores. QSL lead smelters have capacities of 60,000 to 75,000 t/year. Such equipment (with modifications) appears suitable for large-scale GMODS operations. 


\section{STATUS OF DEVELOPMENT}

\section{Thermodynamics}

A preliminary thermodynamics study of the GMODS process has been completed [3] for processing metals and oxides. The analysis indicated that noble metals are not oxidized by $\mathrm{PbO}$ and will dissolve into the lead. (If noble metals build up in the lead, there are standard leadindustry technologies to recover the noble metals.) Copper and less noble materials will form oxides and enter the glass as an oxide.

An analysis of halides in GMODS has been completed recently. Three criteria indicate the efficacy of the use of GMODS in processing halogen-containing wastes: (1) lead halide compounds form when halogens are introduced into GMODS, (2) lead halide compounds are volatile, and (3) most non-lead-metal halides or oxyhalides are unstable in the presence of $\mathrm{PbO}$. Each of these criteria was investigated. The first criterion is satisfied by showing that reactions of the following type are thermodynamically favorable, where $X=\mathrm{F}, \mathrm{Cl}, \mathrm{Br}, \mathrm{I}$ :

$$
\mathrm{PbO}+\mathrm{B}_{2} \mathrm{O}_{3}+2 \mathrm{NaX} \rightarrow \mathrm{Pb} X_{2} \uparrow+\mathrm{Na}_{2} \mathrm{O}: \mathrm{B}_{2} \mathrm{O}_{3}
$$

At temperatures from 800 to $1200^{\circ} \mathrm{C}$, each of these reactions has an equilibrium constant $>1$; therefore, lead halides preferentially form. There may be other borates which result in more stable products than the monoborate, but they would enhance the reactions. Metals other than sodium may be introduced into GMODS with the halides, but sodium is a good representative metal.

Table I gives a set of calculated vapor pressures for lead halides. At $1000^{\circ} \mathrm{C}$ or greater, the vapor pressures of all but lead fluoride $\left(\mathrm{PbF}_{2}\right)$ are $>1$ atm. Although the calculations of the $\mathrm{PbF}_{2}$ vapor pressure are based on recently assessed data, they are conservative. Measured vapor pressures are significantly higher [5] with a vapor pressure of 100 torr $(0.13 \mathrm{~atm})$ at $1077^{\circ} \mathrm{C}$ and a boiling point of $1292^{\circ} \mathrm{C}$. Tests will have to be conducted to determine if the vapor pressure of $\mathrm{PbF}_{2}$ is high enough for effective fluoride removal without the use of a purge gas through the molten glass. The second criterion for halide processing is met.

Table I. Vapor pressures (atm) of lead halides"

\begin{tabular}{cclll}
\hline & \multicolumn{4}{c}{ Vapor pressures (atm) } \\
\cline { 2 - 5 } $\begin{array}{c}\text { Temperature } \\
\left({ }^{\circ} \mathbf{C}\right)\end{array}$ & $\mathbf{P b F}_{\mathbf{2}}$ & $\mathbf{P b C l}_{2}$ & $\mathbf{P b B r}_{\mathbf{2}}$ & $\mathbf{P b I}_{\mathbf{2}}$ \\
\hline 800 & $3.8 \times 10^{-4}$ & $1.7 \times 10^{-1}$ & $2.8 \times 10^{-1}$ & $6.9 \times 10^{-1}$ \\
900 & $2.4 \times 10^{-3}$ & $5.9 \times 10^{-1}$ & $9.0 \times 10^{-1}$ & 2.1 \\
1000 & $1.1 \times 10^{-2}$ & 1.6 & 2.3 & 5.2 \\
1100 & $3.8 \times 10^{-2}$ & 3.7 & 4.9 & $1.1 \times 10^{+1}$ \\
1200 & $1.1 \times 10^{-1}$ & 7.5 & 9.2 & $2.0 \times 10^{+1}$ \\
\hline
\end{tabular}

${ }^{2}$ Methodology based on Ref.[6] and data from Ref.[7]. 
Uranium or plutonium halides or oxyhalides were used to assess whether metal oxides or oxyhalides are stable in the presence of $\mathrm{PbO}$. The following reactions were evaluated by thermochemical calculations in the temperature range of $800-1200^{\circ} \mathrm{C}$.

$$
\begin{aligned}
& \mathrm{PbO}+\mathrm{UOCl}_{2}-\mathrm{PbCl}_{2}(\mathrm{~g}) \uparrow+\mathrm{UO}_{2} \\
& 3 \mathrm{PbO}+\mathrm{UCl}_{6}(\mathrm{~g}) \rightarrow 3 \mathrm{PbCl}_{2}(\mathrm{~g}) \uparrow+\mathrm{UO}_{3} \\
& 2 \mathrm{PbO}+\mathrm{UF}_{4}(\mathrm{~g})-2 \mathrm{PbF}_{2}(\mathrm{~g}) \uparrow+\mathrm{UO}_{2} \\
& \mathrm{PbO}+\mathrm{UOF}_{2}-\mathrm{PbF}_{2}(\mathrm{~g}) \uparrow+\mathrm{UO}_{2} \\
& \mathrm{PbO}+\mathrm{UOF}_{2}-\mathrm{PbF}_{2} \uparrow+\mathrm{UO}_{2} \\
& \mathrm{PbO}+\mathrm{UO}_{2} \mathrm{~F}_{2}-\mathrm{PbF}_{2}(\mathrm{~g}) \uparrow+\mathrm{UO}_{3} \\
& \mathrm{PbO}+2 \mathrm{PuOCl}-\mathrm{PbCl}_{2}(\mathrm{~g}) \uparrow+\mathrm{Pu}_{2} \mathrm{O}_{3} \\
& 3 \mathrm{PbO}+2 \mathrm{PuCl}_{3}-3 \mathrm{PbCl}_{2}(\mathrm{~g}) \uparrow+\mathrm{Pu}_{2} \mathrm{O}_{3}
\end{aligned}
$$

In all cases, the thermodynamic equilibrium constants were $>1$. This finding means that these uranium or plutonium halides or oxyhalides are not stable in the presence of $\mathrm{PbO}$ and that, if introduced into the system, they will be converted to more stable oxides with the formation of volatile lead halides. The conclusion at this stage of GMODS development is that the three criteria for treating halogen-containing wastes can be met.

\section{Investigation of Process Steps}

Some steps of the GMODS process are new, while other steps are parts of standard industrial processes. Experiments were performed to understand and prove the unique features of GMODS. Literature searches have been conducted to understand those parts of the process that are used in other industrial processes.

The addition of feed materials involves oxidation, dissolution, and mixing of feeds with the molten dissolution glass. Tests demonstrated the dissolution of $\mathrm{UO}_{2}, \mathrm{ZrO}_{2}, \mathrm{Al}_{2} \mathrm{O}_{3}, \mathrm{Ce}_{2} \mathrm{O}_{3}, \mathrm{MgO}$, and other oxides. As expected, the glass melt with high concentrations of $\mathrm{B}_{2} \mathrm{O}_{3}$ had good dissolution capabilities for oxides. In analytical chemistry, $\mathrm{B}_{2} \mathrm{O}_{3}$ is the standard chemical reagent for fusion dissolution of unknown oxides because of its capability to dissolve such materials.

Oxidation-dissolution tests demonstrated the oxidation of the following metals and alloys (followed by the dissolution of their oxides into the melt): $\mathrm{U}, \mathrm{Ce}, \mathrm{Zircaloy}-2, \mathrm{Al}$, stainless steel, and other metals. Oxidation-dissolution tests also demonstrated that carbon and graphite are oxidized and that $\mathrm{CO}_{2}$ is produced.

Limited dehalogenation tests with $\mathrm{NaCl}$ demonstrated that lead exits the dissolution glass as $\mathrm{PbCl}_{2}$, thus providing a separation of the chloride from other materials. An Inductively Coupled Plasma Emission Spectrometer (ICP) was used for metals analysis. The experimental apparatus consisted of an alumina crucible which contained the lead borate melt as well as any salt that was added. This was encased in a quartz tube that had entry and exit ports for a carrier gas to enter the system and remove the $\mathrm{PbCl}_{2}$ vapor from above the meit. The off-gas system also had a condenser in the exit gas portion to condense the lead chloride: After exiting the quartz tube the 
off-gas passed through a sodium hydroxide bubbler as well as a sintered metal filter designed to collect the $\mathrm{PbCl}_{2}$.

In the initial chloride reaction experiment, about 5 wt $\%$ of $\mathrm{NaCl}$ was added, the temperature of the melt was increased to $900^{\circ} \mathrm{C}$, and then the carrier gas (argon) was initiated. An aerosol was detected exiting the system. At this point ( $\approx 2 \mathrm{~h}$ since the carrier gas was initiated), the metal filter clogged, and pressure rose in the system until the glass seal was broken. About $1.9 \mathrm{~g}$ of $\mathrm{PbCl}_{2}$ was collected in the off-gas system. However, the efficiency of $\mathrm{PbCl}_{2}$ recovery was low. The low recovery is thought to be a result of several factors including the use of a cool carrier gas that was condensing the $\mathrm{PbCl}_{2}$ chloride vapor back into the melt before the vapor had an opportunity to enter the off-gas system. Additional experiments are planned.

Experimental measurements (Table II) using a rotating platinum cylinder in a platinum cup were made of the viscosity of the dissolution glass with various added materials. Experience in the glass industry indicates that molten glass viscosities should be below $100 \mathrm{cP}$ (about the viscosity of olive oil) for good mixing and creation of homogeneous glasses. This low viscosity is also required for rapid gas release when processing halogen feed materials. Based on our experimental data, the GMODS dissolution glass temperature will need to be between 800 and $1000^{\circ} \mathrm{C}$. The final processing temperature (after the addition of the silica) will be above $1000^{\circ} \mathrm{C}$ because this addition increases glass viscosity.

Table I. Measured viscosities (cP) of lead borate glasses

\begin{tabular}{|c|c|c|c|c|c|}
\hline \multirow[b]{2}{*}{$\mathrm{PbO}: \mathrm{B}_{2} \mathrm{O}_{3}$ ratio } & \multicolumn{5}{|c|}{ Temperature $\left({ }^{\circ} \mathrm{C}\right)$} \\
\hline & 600 & 650 & 700 & 750 & 800 \\
\hline $1: 1$ & & & 260 & 100 & 55 \\
\hline $2: 1$ & 200 & & 45 & & 30 \\
\hline $3: 1$ & 105 & 65 & 45 & & 30 \\
\hline $4: 1$ & 80 & & 60 & & 25 \\
\hline $2: 1$ with 20 wt $\% \mathrm{U}_{3} \mathrm{O}_{8}$ & & $2000^{a}$ & & 125 & \\
\hline $2: 1$ with $10 \mathrm{wt} \% \mathrm{ZrO}_{2}$ & & & & & $560^{a}$ \\
\hline
\end{tabular}

a These viscosity measurements have a greater error $( \pm 200 \mathrm{cP})$ caused by the difficulty with experimental equipment at high viscosities.

Significant industrial experience has occurred in several related technologies that are directly applicable to GMODS. Incinerators and other high-temperature processes with lead and halogens have high losses of lead to off-gas systems because of the volatilization of the lead halides [10]. There is a substantial knowledge about volatile lead halides in high-temperature systems. Addition of glass additives [silicon oxide $\left(\mathrm{SiO}_{2}\right)$ etc.] to improve waste-glass quality is identical to operations used for producing many other waste glasses. The addition of carbon to molten glassy slags to recover molten metal from $\mathrm{PbO}$ in the slag is used in several lead-smelting processes [9] such as the QSL process. Pouring glass from the furnace followed by solidification is a standard operation in the glass industry. Finally, reoxidation of the lead at the bottom of the melter to $\mathrm{PbO}$ by adding $\mathrm{O}_{2}$ is one of several processes used for producing $\mathrm{PbO}$ for batteries and other uses. 


\section{DEVELOPMENTAL PERSPECTIVES}

The analytical evaluations and laboratory development work have demonstrated each step required for GMODS and have identified equipment, instrumentation, and other components needed for GMODS. A significant development effort, however, will be required to convert GMODS into an industrial technology. This effort will include a better understanding of the process, integration of process steps into a system, and development of equipment. A pilot plant will be required to demonstrate the process.

\section{REFERENCES}

1. W. G. Brough and S. T. Boerigter, Plutonium-Bearing Materials Feed Report for the DOE Fissile Materials Disposition Program Alternatives, UCRL-IE-120749, Lawrence Livermore National Laboratory, Livermore, California, April 1995.

2. C. W. Forsberg, E. C. Beahm, and G. W. Parker, Patent Application to the U.S. Office of Trademarks and Patents, U. S. Department of Commerce: The Treatment of Halogen Containing Wastes and Other Waste Materials, May, 181995.

3. C. W. Forsberg, E. C. Beahm, G. W. Parker, J. Rudolph, P. Haas, G. F. Malling, K. R. Elam, L. Ott, Direct Vitrification of Plutonium-Containing Materials With The Glass Material Oxidation and Dissolution System (GMODS), ORNL-6825, Lockheed Martin Energy Systems, Inc., Oak Ridge National Laboratory, Oak Ridge, TN, October 1995.

4. P. E. Queneau and A. Siegmund, JOM, 48 (4), 38 (April 1996).

5 G. Hantke, Gmelins Handbuch Der Anorganischen Chemie: Blei, Vol. 47, Verlag ChemieGMBH, Weinheim, 1969.

6. Outokumpu Research, HSC Chemistry for Windows, Outokumpu, Finland, 1992.

7. W. Slough, and G. P. Jones, Chem. 31, (August 1974).

8. W. P. Linak and J. L. Wendt, Prog. Energ. and Combust. Sci. 19, p. 145 (1993).

9. M. King, "Lead," in Encyclopedia of Chemical Technology, Vol 15, eds. J. I. Kroschwitz and M. Howe-Grant, John Wiley \& Sons, New York, 1995, p.69. 